\title{
Ecotoxicity Evaluation of the Biodegradable Polymers PLA, PBAT and its Blends Using Allium cepa as Test Organism
}

\author{
Paula A. Palsikowski ${ }^{1}$ Matheus M. Roberto ${ }^{2}$ Lais R. D. Sommaggio ${ }^{2}$. \\ Patrícia M. S. Souza ${ }^{1}$ - Ana R. Morales ${ }^{1,3}$ - Maria A. Marin-Morales ${ }^{2}$
}

Published online: 5 April 2017

(C) Springer Science+Business Media New York 2017

\begin{abstract}
Biodegradable polymers are considered a feasible option to minimize the environment impacts of high disposal of solid waste. Nevertheless, environmental safety of these materials is a few explored issue. In this context, this study evaluated ecotoxicological effects in soil of the biodegradable materials poly(lactic acid)-PLA, poly(butylene adipate co-terephthalate)-PBAT and their blends compatibilized with a chain extender. The tool used for this analysis was the bioassay with Allium cepa as test organism. The studied materials were not phytotoxic, cytotoxic, genotoxic nor mutagenic for meristematic cells of A. cepa.
\end{abstract}

Keywords Biodegradable polymers · Ecotoxicity · Bioassay $\cdot$ Allium cepa

\section{Introduction}

Biodegradable polymers have been widely studied for new applications. The contribution related to waste reduction is notorious, but since these new materials are proposed to be disposed directly on the environment (mulch films used for soil covering in agriculture) or indirectly (composting of

Ana R. Morales

morales@feq.unicamp.br

1 Department of Materials Engineering and Bioprocess, School of Chemical Engineering, State University of Campinas (UNICAMP), Campinas, SP, Brazil

2 Department of Biology, Institute of Biosciences, UNESPUniv Estadual Paulista, Rio Claro, Brazil

3 Albert Einstein Avenue, 500-Cidade Universitária, 13083-852 Campinas, SP, Brazil polymeric packages), the eventual risks associated to polymers and its by-products should be assessed.

Most of the biodegradable polymers belong to the polyester group, since ester groups are susceptible to hydrolysis, favouring the formation of low molecular weight substances that can be assimilated by microorganisms and converted into water, carbon dioxide, biomass and degradation products [1]. Poly(butylene adipate-co-terephtalate) (PBAT) and Poly(lactic acid) (PLA) are examples of biodegradable polyesters with potential agriculture applications as soil covering (mulching) [2, 3].

On 1990s, BASF launched the Ecoflex ${ }^{\circledR}$, a PBAT. This is a fossil-based polyester proposed for different applications as agricultural films and packaging [4]. It has also been used in blends with another polyester, PLA (poly lactic acid), aiming to overcome various drawbacks of PLA such as its brittleness and processability limitations [5].

In order to evaluate ecotoxicity related to biodegradable polymers it is important to define timing for assessment. A plastic material can be safe before biodegradation, but may be toxic during degradation. Besides, suitable and sensitive test methods should be considered [6].

Witt et al. identified by gas chromatograph/mass spectroscopy (GC-MS) the by-products of PBAT degradation by the actynomycete Thermomonospora fusca. The solution with intermediates of Ecoflex degradation (1,4-butanediol, adipic acid and terephtalic acid) were tested by Daphnia magna and Photobacterium phosphoreum. In this study no significant toxicological effects were observed [7].

Besides, Ecoflex has been tested for following toxicological assays: terrestrial plant toxicity (OECD 208), earthworm toxicity (OECD 207), primary skin irritation rabbit (OECD 404), primary irritations of the mucus membrane rabbit (OECD 205), guinea pig (OECD 406), $\mathrm{LD}_{50}$ rat (OECD 423) and Ames test (OECD 471). The tests 
evaluated ecotoxicological effects of degradation intermediates as well as the product safety during the use phase and no adverse effects were verified [4].

The majority of published studies related to ecotoxicity of biodegradable polymers are focused on germination assays on plants such as: radish, rice and beans [8-10]. According to ASTM D6400 [11], the standard related to certification of compostable plastics, the ecotoxicological test recommended to access terrestrial safety is evaluation of germination rate and plant biomass, using the guide OECD 208 for two different plant species.

In this context it is important to consider that some plant species are capable of offering a more detailed ecotoxicological information as cytotoxic, genotoxic and mutagenic effects associated to polymers degradation process [12]. The Allium cepa test has been applied for environmental monitoring to detect different classes of pollutants and also complex mixtures, such as water and soil samples from contaminated areas [13].

Souza et al. [12] reported that A. cepa could be an efficient tool to study ecotoxicity related to degradation of pure PLA and nanocomposites with in composting process, including quantifications of mitotic index, chromosomal aberrations and micronucleus. In this study the compost samples after degradation of the polymer did not presented mutagenic effects and the types of the observed chromosomal aberrations indicated a possible genotoxic effect of the materials, which may be related to an aneugenic action of PLA degradation products.

The mitotic index (MI), characterized by the ratio of dividing cells and total cells observed, could be used as a parameter for evaluating the cytotoxicity of various agents [13].

The term genotoxic is used to describe an agent capable of promoting DNA damage. Chromosomal aberrations as C-metaphases, polyploid metaphases, metaphases with adherences, metaphases with chromosomal losses, anaphases and telophases with delays, losses, chromosomal bridges and nucleus abnormalities are examples of alterations which can be considered genotoxic evidences [13, 14].

The micronuclei have been considered by many authors as the most effective and simplest endpoint to analyze mutagenic effect induced by chemicals. A mutation is defined as a change in the DNA sequence that leads to heritable genetic changes. The micronucleus appears in daughter cells as a result of damage induced in parental cells [15].

This paper will present recent results from A. cepa bioassay applied to evaluate cytotoxic, genotoxic and mutagenic effects in soil after degradation of different biodegradable polymeric materials. The tested polymers were poly(lactic acid)_PLA, poly(butylene adipate-co-terephthalate)PBAT and their blends. These materials were previously studied in terms of thermal and mechanical behavior [16] and biodegradation in soil [17].

\section{Experimental Procedure}

\section{Materials}

The preparation of polymers and blends samples were made using the following materials: poly(butylene adipateco-terephtalate)-PBAT, grade Ecoflex F BX 7011 (BASF); poly(lactic acid)-PLA, grade 4042D (Natureworks) and the chain extender- CE, grade Joncryl ADR-4368 (BASF).

The blend nominated $25 / 75$ was prepared using $25 \%$ by weight (wt.) of PLA and 75\% wt of PBAT. The blend 75/25 was prepared with $75 \%$ wt. of PLA and $25 \%$ wt of PBAT. For all the samples it was added at 1 pcr (parts per 100 parts of resin). Notations and compositions of the studied materials are detailed in Table 1.

The samples were prepared previously by Kuchnier [16] in a torque rheometer HAAKE Rheomix 600P during $5 \mathrm{~min}$, at $120 \mathrm{rpm}$ and $180^{\circ} \mathrm{C}$. After that, samples with a thickness of $0.3 \mathrm{~mm}$ were obtained in a press Labtech Engineering Co. Ltd., model LP20B at a constant pressure of $800 \mathrm{psi}$, and temperatures of $120^{\circ} \mathrm{C}$ (PBAT), $160^{\circ} \mathrm{C}$ (PLA) and $150{ }^{\circ} \mathrm{C}$ (blends).

\section{Characteristic and Sample Preparation}

The samples were submitted to disintegration in soil. According to Innocenti [18], in order to have a good chance to detect possible negative effects, it is advisable to apply high initial concentrations of the polymer under study. A 'high' concentration is considered to be one that is at least 1-2 order of magnitude greater than the normal dose used in real applications. So, if at high concentrations there is no effect observed, the environmental risk at normal doses is negligible.

In this work the concentration of each material in soil was calculated according to Innocenti [18], based on the sample thickness and considering the value of $1 \mathrm{~g} / \mathrm{cm}^{3}$ for soil apparent density in São Paulo State [19]. Table 2 shows the thickness, density and mass of each sample used in a mixture with $200 \mathrm{~g}$ of soil (suitable for the bioassay test).

Table 1 Compositions of samples (PLA, PBAT and blends)

\begin{tabular}{lccl}
\hline Sample name & PLA $(w t \%)$ & PBAT $(w t \%)$ & CE (phr) \\
\hline PLA & 100 & 0 & 1 \\
PBAT & 0 & 100 & 1 \\
$75 / 25$ & 75 & 25 & 1 \\
$25 / 75$ & 25 & 75 & 1
\end{tabular}


Table 2 Thickness, density and mass of polymeric samples used in ecotoxicity test

\begin{tabular}{lcccc}
\hline Material & PLA & $75 / 25$ & $25 / 75$ & PBAT \\
\hline Thickness $(\mathrm{cm})$ & 0.30 & 0.32 & 0.28 & 0.30 \\
Density $\left(\mathrm{g} / \mathrm{cm}^{3}\right)$ & 1.24 & 1.25 & 1.26 & 1.27 \\
Mass $(\mathrm{g})$ & 20.9 & 21.70 & 19.3 & 20.6 \\
\hline
\end{tabular}

The plastic samples with a thickness of $0.3 \mathrm{~mm}$ were cut into square pieces of $1 \mathrm{~cm}^{2}$. The mass reported in Table 2 of each material was mixed with $200 \mathrm{~g}$ of the environment matrix, consisted of different soils collected in December of 2013 in the campus of State University of Campinas (São Paulo State- Brazil), in a house yard also located in Campinas and a garden located in the city of São Jorge d'Oeste (Paraná State-Brazil). The mixture was done following an recommendation of ASTM D5988 [20] for biodegradation tests of plastics, that indicates to make a laboratory mixture of equal parts (by weight) of soil samples obtained from at least three diverse locations in order to maximize biodiversity of microorganisms.

The characterization of this mixture of soils is presented in Table 3. The determination of soil moisture was made at $105{ }^{\circ} \mathrm{C}$ for $24 \mathrm{~h}$. The water holding capacity was determined according to the methodology described by Casado [21]. The parameters of organic matter, nitrogen and $\mathrm{pH}$ were quantified according to the methods described by MAPA [22]. The result for organic carbon was obtained by dividing the result of organic matter for 1.8 , as proposed by Kiehl [23].

Each mixture of soil and samples was added in a $1 \mathrm{~L}$ vessel. In a separated vessel it was added just $200 \mathrm{~g}$ of pure soil. The vials were kept at room temperature for 6 months. After this period it was observed a low level of disintegration. In order to promote degradation process the vessels were placed in an oven at controlled temperature $\left(60^{\circ} \mathrm{C}\right)$ for 2 months until the disintegration of samples. The higher temperature was chosen to be close of the PLA's Tg in order to promote hydrolytic degradation since it increases free volume in polymeric materials, enhancing the chain mobility and water diffusion [24]. During degradation

Table 3 Soil characterization

\begin{tabular}{lc}
\hline Parameters & Results \\
\hline Moisture (\%) & 45.1 \\
Water holding capacity $(\%)$ & 75.2 \\
Organic matter $\left(\mathrm{g} / \mathrm{dm}^{3}\right)$ & 45.0 \\
Organic carbon $\left(\mathrm{g} / \mathrm{dm}^{3}\right)$ & 40.0 \\
Nitrogen $(\mathrm{g} / \mathrm{Kg})$ & 2.7 \\
$\mathrm{C} / \mathrm{N}$ & 14.8 \\
\hline
\end{tabular}

period, aeration was promoted by turning the soil periodically (every 2 days).

After this period the aqueous extract of soil samples were obtained based on the standard ABNT 10006-04 [25] by mixing $200 \mathrm{~g}$ of each sample (dry weight) and $800 \mathrm{~mL}$ of water. The moisture after disintegration process in soil was calculated at $105^{\circ} \mathrm{C}$ by $24 \mathrm{~h}$. The moisture, the wet mass and the quantity of added water in each sample for preparing the solubilized are shown in Table 4.

After stirring the mixtures of water/soil for $5 \mathrm{~min}$, the vessels were covered with PVC film and kept on standing for a period of 7 days at $22^{\circ} \mathrm{C}$. The supernatant was filtered using a membrane with $0.45 \mu \mathrm{m}$ of porosity.

\section{Bioassay with Allium cepa Organism}

Seeds of A. cepa from variety Baia Periforme were arranged in Petri dishes lined with filter paper (100 seeds per plate, two plates per treatment). The seeds were subjected to germination with samples of aqueous extract in incubator at $22 \pm 2{ }^{\circ} \mathrm{C}$. A negative control (NC) was performed with ultrapure water. Also, a positive control was performed by using methylmethane sulfonate (MMS) at a concentration of $4 \times 10^{-4} \mathrm{M}$, which has a renowned clastogenic action [26], and the trifluralin herbicide (TRF) at the concentration of $0.84 \mathrm{ppm}$, which has an aneugenic action already described [14]. The bioassay was performed based in two independent exposures in two different batches, each one with two replicates per treatment.

After reaching about $1.5 \mathrm{~cm}$ in length, the roots were collected and fixed with Carnoy solution (ethanol/acetic acid- $3: 1-\mathrm{v} / \mathrm{v}$ ) for $6 \mathrm{~h}$ at room temperature. After this time, the fixative was replaced by a recently prepared solution. The roots were stored at $4{ }^{\circ} \mathrm{C}$ until the slides preparation. The test with meristematic cells of A. cepa was performed based on the protocol established by Grant [27] with some modifications. The fixed roots were subjected to the Feulgen reactive (Schiff's solution), which reacts specifically with DNA. For the preparation of the slides, the meristems were placed on slides containing a drop of acetic carmine (2\%), covered with coverslips, and

Table 4 Data quantified for the preparation of solubilized

\begin{tabular}{llll}
\hline Soil sample & Moisture $(\%)$ & Wet mass $(\mathrm{g})$ & $\begin{array}{l}\text { Volume of dis- } \\
\text { tilled added water } \\
(\mathrm{mL})\end{array}$ \\
\hline PLA & 47 & 378.1 & 621.8 \\
PBAT & 46 & 374.0 & 626.0 \\
$75 / 25$ & 48 & 381.7 & 618.3 \\
$25 / 75$ & 50 & 396.3 & 603.7 \\
Solo & 44 & 356.3 & 643.7 \\
\hline
\end{tabular}


gently squashed. After the removal of the coverslips in liquid nitrogen, the permanent slides were prepared with synthetic resin.

The analysis of slides was performed in a light microscope (Nikon, model Eclipse E200), using a 100× objective. Around 5000 cells were counted per treatment, being 500 cells counted per slide and five slides evaluated for each replicate.

The phytotoxicity was analyzed by Germination Index (GI), calculated according to Eq. 1:

$\mathrm{GI}=\frac{\text { total number of germinated seeds }}{\text { total number of exposed seeds }} \times 100$

The cytotoxicity was assessed by Mitotic Index (MI) calculation, acquired by the ratio between the total number of cells on division (counting cells in different mitosis phases: prophase, metaphase, anaphase and telophase) and the total number of observed cells, according to Eq. 2.

$\mathrm{MI}=\frac{\text { total number of cells on division }}{\text { total number of observed cells }} \times 100$

The genotoxicity was accessed by the Chromosomal Alterations Index (CAI), calculated according to Eq. 3, considering the number of cells carrying chromosomal aberrations (adherence, polyploidy, loss, C-methaphase, multipolarity, bridge and loss) and nuclear abnormalities (binucleated cell, trinucleated cell and lobulated nucleus).

$\mathrm{CAI}=\frac{\text { total number of altered cells }}{\text { total number of observed cells }} \times 100$

The mutagenicity endpoint was based on the presence of micronucleated cells and the Mutagenicity Index (MutI) was calculated according to Eq. 4.

Mult $=\frac{\text { total number of altered cells }}{\text { total number of observed cells }} \times 100$

The statistical analysis was performed using the software BioEstat 5.3 (Mamirauá Institute, Brazil). The parameters GI and MI were evaluated by ANOVA-One Way $(p<0.05)$, since the results presented a normal distribution. The CAI and MutI did not presented normal distribution and, in this case, the results were evaluated by Kruskal-Wallis method $(\mathrm{p}<0.05)$.

\section{Results and Discussion}

The results showed that, overall, there was no significant germination inhibition by the samples, when they were compared with the negative control. Exception occurred for the treatments with PLA and MMS, but it happened just for one of the batches of experiment for each treatment (Fig. 1).

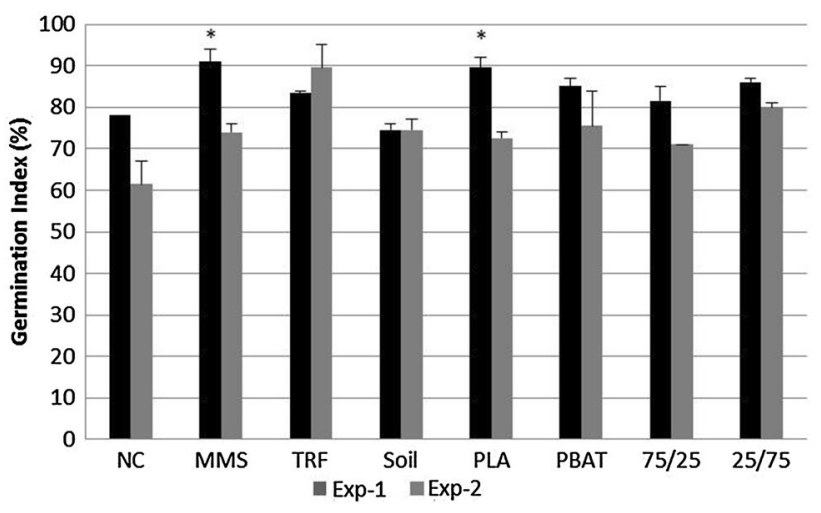

Fig. 1 Germination index for PLA, PBAT and its blends (*Statistically significant, $\mathrm{p}<0.05$-ANOVA-One Way)

The A. cepa species is one of the recommended organisms by OECD-208 [28] for ecotoxicity evaluations. Nevertheless in the field of biodegradable polymers it was not found ecotoxicological studies in the literature reporting this test organism.

Rudeekit et al. [10] evaluated blends of PLA and starch after composting based on OECD-208 [28], where the parameters quantified were: rate of germination and growth of plants Oryza sativa (monocotyledonae) and Vigna radiata (dicotyledonae).

Mitelut and Popa [9] studied the degree of toxicity of PLA/PBAT/lignin blends after composting using the germination of Raphanus sativus as a parameter, following the methodology proposed by Gariglio et al. [29].

This shortage of information highlights the importance of ecotoxicology studies for biodegradable polymers, which could consider different test organisms in addition to the different environments where these materials can be disposed off after their useful life (soil, composting, landfills). Therefore, the A. cepa organism is able to support analysis in this relevant field.

None of the treatments presented Mitotic Index (MI) significantly different from the negative control. So, the materials PLA, PBAT and its blends (25/75 and 75/25) showed to be not cytotoxic for A. cepa organism (Fig. 2).

The Chromosomal Alterations Index (CAI) showed significant values for the positive controls with trifluralin (TRF) and methylmethane sulfonate (MMS) (Fig. 3).

Chromosomal aberrations are based on changes in the structure or number of chromosomes of cells, which can occur spontaneously or as a result of action of chemical or physical agents. Changes in chromosome structure may be induced by inhibition of DNA synthesis, by replication of the modified DNA, or by breaks in the DNA strand, characterizing a so-called clastogenic effect. The occurrence of micronucleus is result of genotoxic events that were not repaired or repaired wrongly in the parental cell, resulting 


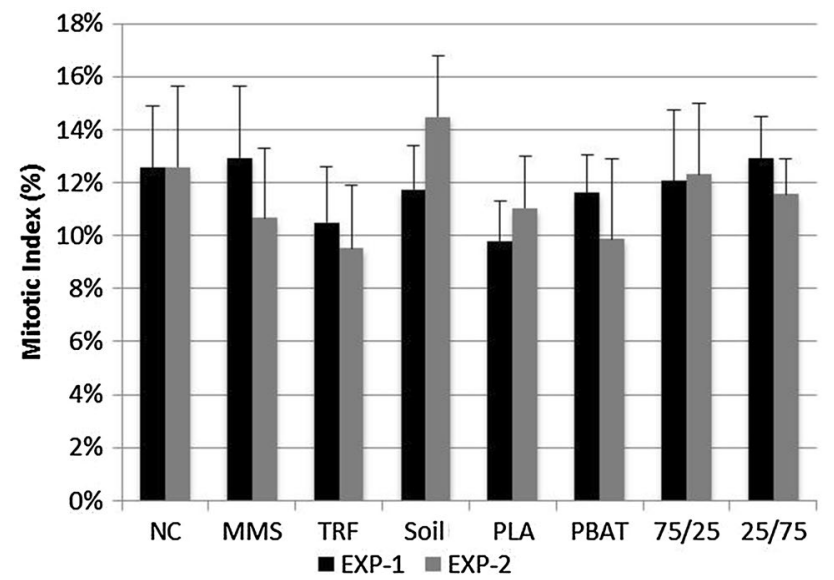

Fig. 2 Results for Mitotic Index (*Statistically significant, $\mathrm{p}<0.05-$ ANOVA-One Way)

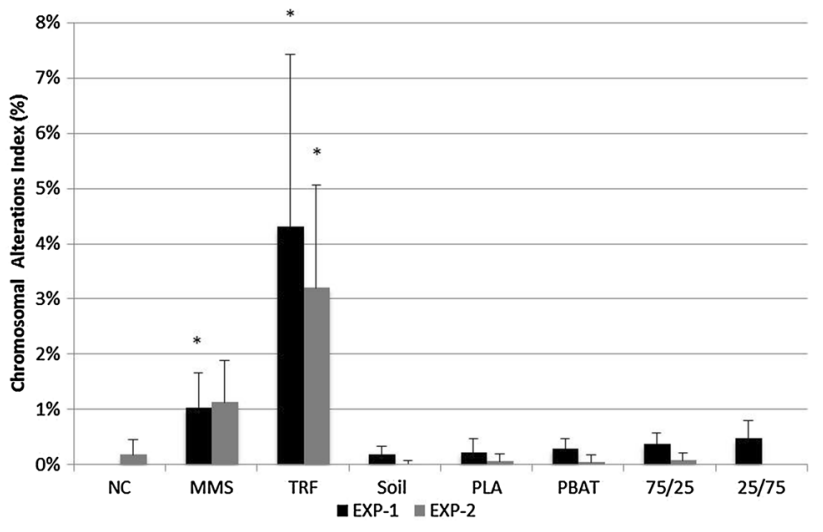

Fig. 3 Results for Chromosomal Alterations Index (*Statistically significant, $\mathrm{p}<0.05$-Kruskal-Wallis)

in chromosomal breaks that form the micronuclei. The changes in the number of chromosomes, as observed in aneuploid and polyploid cells, may be a result from abnormal segregation of chromosomes during the cell division, that occur spontaneously or by the influence of aneugenic agents. The MNs can still be formed by action of the toxic agent on proteins or cytoplasmic structures, such as mitotic spindles, which result in losses of whole chromosomes and consequently in the formation of MNs in daughter cells [13].

Leme and Marin-Morales [13] state that the A. cepa test is an excellent indicator of genotoxicity and mutagenicity promoted by toxic agents. The presence of chromosomal aberrations and micronuclei in A. cepa cells is a signal that the agent has genotoxic or mutagenic potential respectively, which supports its applicability to detect both classes of damages, being this assay recommended to assess the effects of environmental chemicals or pollutants.
According to Fernandes et al. [30] the 0.84 ppm concentration of herbicide can be regarded as "diagnostic concentration" for genotoxicity, since it causes high rates of chromosomal aberrations and nuclear abnormalities, indicating an aneugenic effect. The other positive control, MMS, also presented significant values of CAI related to negative control. It is also expected considering its ability to induce chromosomal aberrations [26].

Among the tested materials, one of the experiments presented a significant CAI in comparison to negative control. It happened for the blend $25 / 75$, but this behavior was not observed for the second experimental batch. Palsikowski et al. [17] monitored the number-average molecular weight $(\mathrm{Mn})$ of these materials during degradation in soil at different periods $(0,60,120,180,240,300$ and 360 days) at room temperature. It was observed that for all the periods the pure PBAT and the blend 25/75 presented the lowest values of Mn. This parameter is sensible to low molecular weight species in the sample. Therefore, it is possible to infer that the solubilized samples from soils after degradation of PBAT and 25/75 may contain degradation products at higher concentrations than other materials evaluated.

Palsikowski et al. [17] also studied the mineralization rate of all the materials in soil during 120 days. The mineralization after this period for PBAT and 25/75 was similar-16 and $11 \%$, respectively. So, the main difference between the both solubilized could be that $25 / 75$ would have more degradation products derived from PLA. Therefore, the significant result of CAI for one of experiments with the blend 25/75 may be associated to PLA degradation products. Souza et al. [12] also observed values of CAI statistically significant associated to degradation of PLA in compost environment using A. сера as test organism. Since in the present study this result was not observed in the second experiment, new assays are necessary to consolidate and better clarify this behavior. The frequencies of alterations observed among the different treatments are presented on Table 5. Figure 4 shows A. cepa cells with different chromosomal aberrations.

At least one of the experiments with the solubilized samples tested presented aberrations as chromosomal breakages and nuclear bud. The breaks are promoted by clastogenic effect and can be observed at higher frequencies in the case of MMS, a compound that is known for its clastogenic action [23].

The treatments with PLA or PBAT induced aberration as $\mathrm{C}$-metaphase. This aberration is possibly reversible [31] but if no repairs occur, polyploid cells may be formed.

Among the nuclear alterations, the most frequent was nuclear bud, that can be a consequence of breaks, bridges and delays, since in these cases the chromosomes or fragments can not be incorporated to the main nucleus of the cell [32]. 
Table 5 Chromosomal alterations evaluated in Allium cepa cells after germination in different samples and blends of PLA and PBAT (average \pm standard deviation-\%)

\begin{tabular}{|c|c|c|c|c|c|c|c|c|c|}
\hline Alterations & Experiment & $\mathrm{CN}$ & MMS & TRIF & SOIL & PLA & $75 / 25$ & $25 / 75$ & PBAT \\
\hline \multirow[t]{2}{*}{ Chromosomal break } & 1 & $0.00 \pm 0.00$ & $0.26 \pm 0.20$ & $0.06 \pm 0.09$ & $0.02 \pm 0.05$ & $0.09 \pm 0.16$ & $0.06 \pm 0.09$ & $0.07 \pm 0.16$ & $0.04 \pm 0.08$ \\
\hline & 2 & $0.09 \pm 0.12$ & $0.19 \pm 0.20$ & $0.05 \pm 0.12$ & $0.00 \pm 0.00$ & $0.04 \pm 0.12$ & $0.02 \pm 0.06$ & $0.00 \pm 0.00$ & $0.04 \pm 0.08$ \\
\hline \multirow[t]{2}{*}{ Nuclear bud } & 1 & $0.00 \pm 0.00$ & $0.36 \pm 0.47$ & $0.95 \pm 0.49$ & $0.06 \pm 0.09$ & $0.36 \pm 0.34$ & $0.26 \pm 0.22$ & $0.39 \pm 0.28$ & $0.19 \pm 0.13$ \\
\hline & 2 & $0.07 \pm 0.23$ & $0.81 \pm 0.60$ & $0.71 \pm 0.45$ & $0.00 \pm 0.00$ & $0.02 \pm 0.06$ & $0.04 \pm 0.08$ & $0.00 \pm 0.00$ & $0.06 \pm 0.18$ \\
\hline \multirow[t]{2}{*}{ Chromosomal adherence } & 1 & $0.00 \pm 0.00$ & $0.00 \pm 0.00$ & $0.00 \pm 0.00$ & $0.00 \pm 0.00$ & $0.00 \pm 0.00$ & $0.00 \pm 0.00$ & $0.00 \pm 0.00$ & $0.04 \pm 0.08$ \\
\hline & 2 & $0.00 \pm 0.00$ & $0.00 \pm 0.00$ & $0.00 \pm 0.00$ & $0.00 \pm 0.00$ & $0.00 \pm 0.00$ & $0.00 \pm 0.00$ & $0.00 \pm 0.00$ & $0.00 \pm 0.00$ \\
\hline \multirow[t]{2}{*}{ Chromosomal bridge } & 1 & $0.00 \pm 0.00$ & $0.02 \pm 0.06$ & $0.11 \pm 0.15$ & $0.02 \pm 0.06$ & $0.04 \pm 0.13$ & $0.00 \pm 0.00$ & $0.00 \pm 0.00$ & $0.00 \pm 0.00$ \\
\hline & 2 & $0.00 \pm 0.00$ & $0.04 \pm 0.12$ & $0.09 \pm 0.13$ & $0.00 \pm 0.00$ & $0.00 \pm 0.00$ & $0.00 \pm 0.00$ & $0.00 \pm 0.00$ & $0.02 \pm 0.06$ \\
\hline \multirow[t]{2}{*}{ Chromosomal loss } & 1 & $0.00 \pm 0$ & $0.27 \pm 0.34$ & $0.02 \pm 0.06$ & $0.00 \pm 0.00$ & $0.00 \pm 0.00$ & $0.00 \pm 0.00$ & $0.00 \pm 0.00$ & $0.00 \pm 0.00$ \\
\hline & 2 & $0.02 \pm 0.06$ & $0.07 \pm 0.18$ & $0.17 \pm 0.14$ & $0.02 \pm 0.06$ & $0.00 \pm 0.00$ & $0.02 \pm 0.06$ & $0.00 \pm 0.00$ & $0.00 \pm 0.00$ \\
\hline \multirow[t]{2}{*}{ C-metaphase } & 1 & $0.00 \pm 0.00$ & $0.02 \pm 0.05$ & $0.00 \pm 0.00$ & $0.00 \pm 0.00$ & $0.02 \pm 0.06$ & $0.00 \pm 0.00$ & $0.00 \pm 0.00$ & $0.02 \pm 0.06$ \\
\hline & 2 & $0.00 \pm 0.00$ & $0.02 \pm 0.06$ & $0.33 \pm 0.40$ & $0.00 \pm 0.00$ & $0.00 \pm 0.00$ & $0.00 \pm 0.00$ & $0.00 \pm 0.00$ & $0.00 \pm 0.00$ \\
\hline \multirow[t]{2}{*}{ Multipolar anaphase } & 1 & $0.00 \pm 0.00$ & $0.00 \pm 0.00$ & $0.00 \pm 0.00$ & $0.02 \pm 0.06$ & $0.00 \pm 0.00$ & $0.00 \pm 0.00$ & $0.00 \pm 0.00$ & $0.00 \pm 0.00$ \\
\hline & 2 & $0.00 \pm 0.00$ & $0.00 \pm 0.00$ & $0.17 \pm 0.19$ & $0.00 \pm 0.00$ & $0.00 \pm 0.00$ & $0.00 \pm 0.00$ & $0.00 \pm 0.00$ & $0.00 \pm 0.00$ \\
\hline \multirow[t]{2}{*}{ Binucleated cell } & 1 & $0.00 \pm 0.00$ & $0.00 \pm 0.00$ & $0.73 \pm 0.77$ & $0.06 \pm 0.12$ & $0.00 \pm 0.00$ & $0.00 \pm 0.00$ & $0.00 \pm 0.00$ & $0.00 \pm 0.00$ \\
\hline & 2 & $0.00 \pm 0.00$ & $0.00 \pm 0.00$ & $0.07 \pm 0.18$ & $0.00 \pm 0.00$ & $0.00 \pm 0.00$ & $0.00 \pm 0.00$ & $0.00 \pm 0.00$ & $0.00 \pm 0.00$ \\
\hline \multirow[t]{2}{*}{ Trinucleated cell } & 1 & $0.00 \pm 0.00$ & $0.00 \pm 0.00$ & $0.08 \pm 0.13$ & $0.00 \pm 0.00$ & $0.00 \pm 0.00$ & $0.00 \pm 0.00$ & $0.00 \pm 0.00$ & $0.02 \pm 0.06$ \\
\hline & 2 & $0.00 \pm 0.00$ & $0.00 \pm 0.00$ & $0.00 \pm 0.00$ & $0.00 \pm 0.00$ & $0.00 \pm 0.00$ & $0.00 \pm 0.00$ & $0.00 \pm 0.00$ & $0.00 \pm 0.00$ \\
\hline \multirow[t]{2}{*}{ Polynucleated cell } & 1 & $0.00 \pm 0.00$ & $0.00 \pm 0.00$ & $0.04 \pm 0.12$ & $0.02 \pm 0.06$ & $0.00 \pm 0.00$ & $0.00 \pm 0.00$ & $0.00 \pm 0.00$ & $0.00 \pm 0.00$ \\
\hline & 2 & $0.00 \pm 0.00$ & $0.00 \pm 0.00$ & $0.04 \pm 0.12$ & $0.00 \pm 0.00$ & $0.00 \pm 0.00$ & $0.00 \pm 0.00$ & $0.00 \pm 0.00$ & $0.00 \pm 0.00$ \\
\hline \multirow[t]{2}{*}{ Lobulated cell } & 1 & $0.00 \pm 0.00$ & $0.11 \pm 0.20$ & $2.27 \pm 2.08$ & $0.02 \pm 0.06$ & $0.02 \pm 0.06$ & $0.02 \pm 0.06$ & $0.00 \pm 0.00$ & $0.09 \pm 0.17$ \\
\hline & 2 & $0.00 \pm 0.00$ & $0.02 \pm 0.06$ & $1.56 \pm 1.32$ & $0.00 \pm 0.00$ & $0.00 \pm 0.00$ & $0.00 \pm 0.00$ & $0.00 \pm 0.00$ & $0.00 \pm 0.00$ \\
\hline
\end{tabular}

Lobulated nuclei were also observed. Nevertheless, significant results were observed only for trifluralin. This aberration may be formed by chromosomal bridges in multipolar anaphases, which can be involved by a nuclear envelope [33]. The presence of lobulated nucleus can indicate cell death, since these alterations are not observed on F1 cells of A. cepa organism [34].

The unique experiment that presented chromosomal adherence was the one related to PBAT. This kind of alteration indicates toxic effect of the material, which can promote irreversible damages to cells, including cell death [34, 35].

The Mutagenicity Index (MutI) results are showed in Fig. 5.

Statistically significant values were obtained for MutI in the case of MMS, due to the higher frequency of chromosomal breakages and micronucleus that can be attributed to clastogenic effect of the substance. This behavior indicates an adequate response of the system, since this substance is used as a positive control for mutagenicity [36].

The treatments conducted with trifluralin also showed statistically significant values for MutI. It may be associated with its aneugenic action because the inactivation of mitotic fuse prevents the migration of chromosomes to the poles of the cell, which once dispersed in the cytoplasm, leads to losses that can induce micronucleus formation [14].

The treatments with PLA, PBAT and its blends did not show statistically significant values of MutI, so none of these materials presented mutagenic effects on A. сера species.

\section{Conclusion}

The bioassay with the test organism A. cepa was a sensitive tool for assessment of ecotoxicity of soil samples after PBAT, PLA and its blends disintegration.

In general the studied materials did not present any cytotoxic, genotoxic and mutagenic effects on meristematic cells of A. cepa. An exception occurred for the blend 25/75, in which one of the experiments presented chromosomal aberration index statistically significant related to negative control. Although it was not observed in the experiment repetition (Exp. 2), it is not negligible. New experiments are recommended for all materials, in order to consolidate the information about ecotoxicological effects from degradation products of polymeric materials. In a following study it is recommended to include analysis on cells from F1 region, which are cells derived from mitotic division 

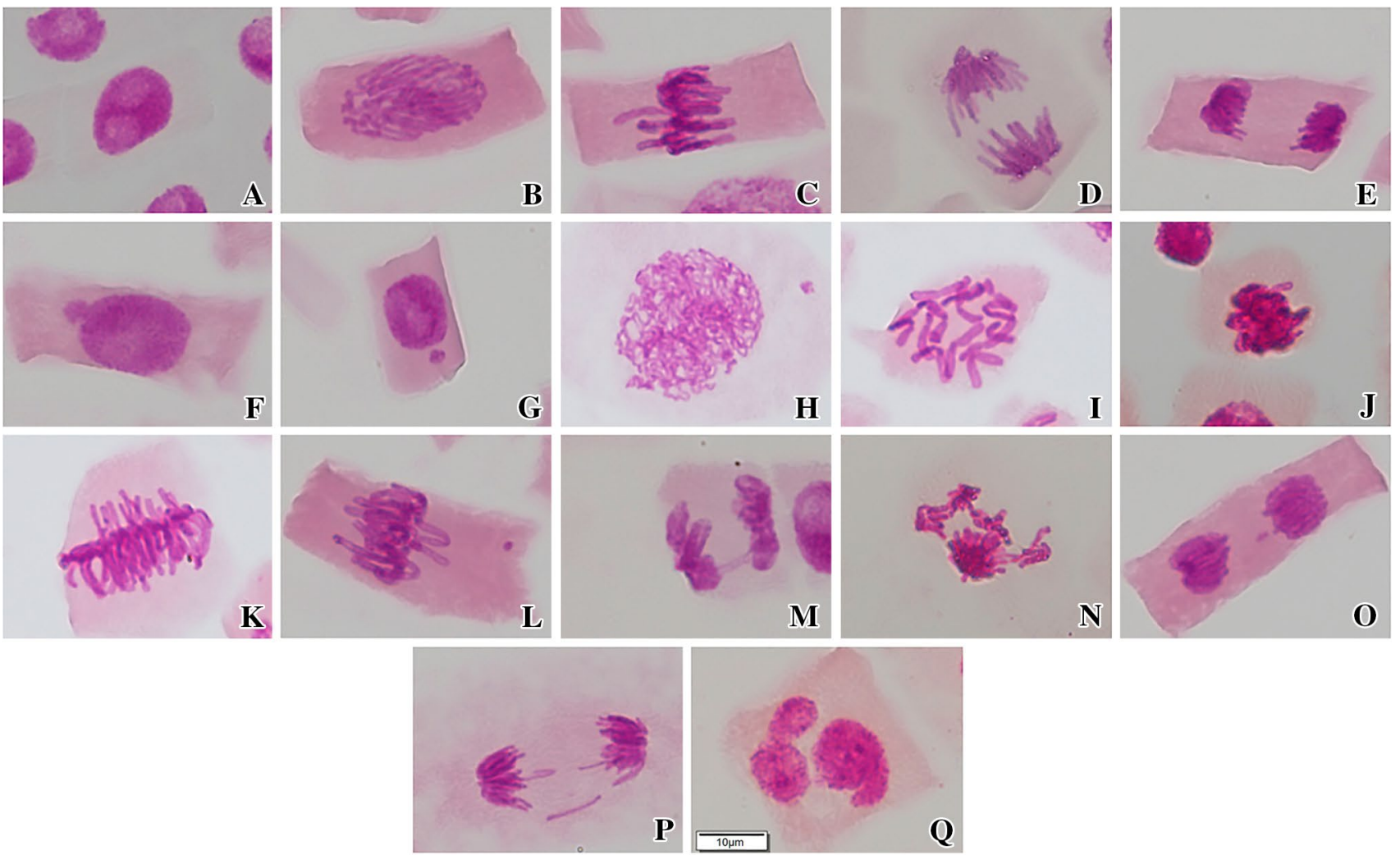

Fig. 4 Chromosomal aberrations observed in Allium cepa meristematic cells: a normal interphase; b normal prophase; c normal metaphase; d normal anaphase; e normal telophase; $\mathbf{f}$ interphase with nuclear bud; $\mathbf{g}$ micronucleated cell in interphase; $\mathbf{h}$ micronucleated and polyploid cell in prophase; i C-metaphase; $\mathbf{j}$ metaphase

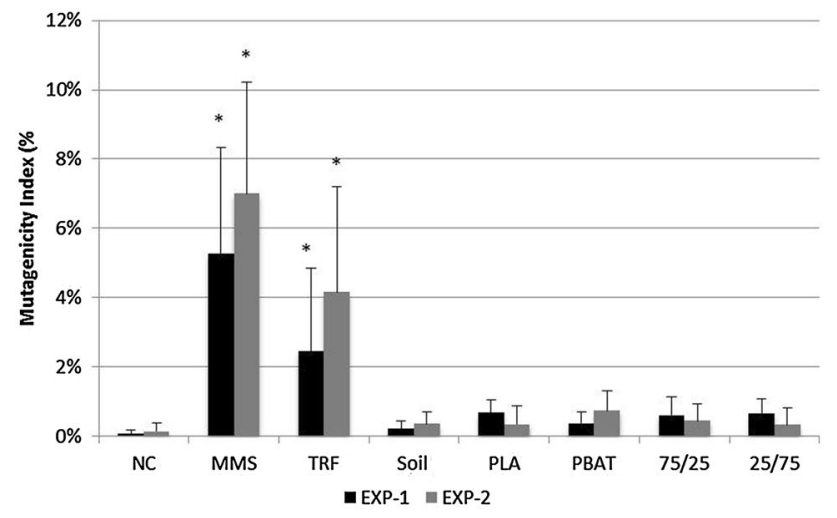

process and to indicate the byproducts in solubilized samples from soil.

Acknowledgements The authors would like to thank you the Foundation for Research of the State of São Paulo - FAPESP (Process 2014/09883-5) and National Council of Scientific and Technological Development CNPQ for the financial support.

Fig. 5 Results for Mutagenicity Index (*Statistically significant, $\mathrm{p}<0.05$-Kruskal-Wallis)

of meristematic cells and could prove the permanence of damages. Besides, for a better understanding of ecological impact related to biodegradable materials it is important to consider new researches with different test organisms (plants, algae, annelids, bacteria, human cells). Also, parallel chemical analysis would permit to detail degradation

with adherence; $\mathbf{k}$ polyploid metaphase; $\mathbf{l}$ micronucleated cell in metaphase; $\mathbf{m}$ anaphase cell with chromosomal bridge; $\mathbf{n}$ multipolar anaphase; $\mathbf{o}$ telophase with chromosomal breakage; $\mathbf{p}$ telophase with chromosomal loss; $\mathbf{q}$ binucleated and lobulated cell

\section{References}

1. Rizzareli P, Carroccio S (2014) Anal Chim Acta 808:18

2. Jandas PJ, Mohant S, Nayak SK (2013) Ind Eng Chem Res $52: 17714$

3. Kijchavengkul T, Auras R, Rubino M, Selke S, Ngouajio M, Fernandez RT (2011) Polym Degrad Stab 96:1919

4. Siegenthaler KO, Künkel A, Skupin G, Yamamoto M (2012) Ecoflex and Ecovio: biodegradable, performance-enabling plastics. In: Abe A, Albertsson A-C, Dusek K, Genzer J, Jeu WH, Kobayashi S, Lee K-S, Leibler L, Long TE, Manners I, Möller M, Terentjev EM, Vicent M, Voit B, Wegner G, Wiesner U (eds) Advances in polymer science 245. Springer, Berlin, pp 91-136

5. Nofar M, Heuzey MC, Carreau PJ, Kamal MR, Randall J (2016) J Rheol 60:637

6. Innocenti FD (2014) Front Microbiol 5:475 
7. Witt U, Einig T, Yamamote M, Kleeberg I, Decwer WD, Müller RJ (2001) Chemosphere 44:289

8. César MEF, Mariani PDSC, Innocentini-Mei LH, Cardoso EJBN (2009) Polym Testing 28:680

9. Mitelut C, Popa ME (2011) Rom Biotechnol Lett 16:121

10. Rudeekit Y, Siriyota P, Intaraksa P, Chaiwutthinan P (2012) Adv Mater Res 506:323

11. ASTM D6400-12. Standard specification for labeling of plastics designed to be aerobically composted in municipal or industrial facilities

12. Souza PMS, Corroqué NA, Morales AR, Marin-Morales MA, Mei LH (2013) J Polym Environ 21:1052

13. Leme M, Marin-Morales MA (2009) Mutat Res 682:71

14. Fernandes TCC, Mazzeo DEC, Marin-Morales MA (2007) Pestic Biochem Physiol 88:252

15. Serres FJ (1978) Environ Health Perspect 27:3

16. Kuchnier CN (2014) Estudo do efeito de aditivo extensor de cadeia multifuncional em blendas de PLA/PBAT. Dissertação de Mestrado em Engenharia Química, Faculdade de Engenharia Química-UNICAMP, Campinas, SP

17. Palsikowski PA, Kuchnier CN, Pinheiro IF, Morales AR (2017) Biodegradation in soil of PLA/PBAT blends compatibilized with chain extender. J Polym Environ 1-12

18. Innocenti FD (2005) In: Bastioli C (ed) Handbook of biodegradable polymeric materials and their applications. American Scientifica Publishers, Valencia

19. Setzer J (1941) Bragantia 1:255

20. ASTM D5988-12. Standard test method for determing aerobic biodegradation of plastic materials in soil

21. Casado EB (2009) Desenvolvimento e caracterização de blendas de poliéster sintético biodegradável com proteína de soja e estudo de biodegradação em solo. Dissertação de Mestrado em Engenharia Química-Departamento de Tecnologia de Materiais, Faculdade de Engenharia Química-UNICAMP, Campinas, SP
22. MAPA-Ministério da Agricultura, Pecuária e Abastecimento (2007) Instrução Normativa No. 28: Manual de Métodos Analíticos Oficiais para Fertilizantes Minerais, Orgânicos, Organo-minerais e Corretivos

23. Kiehl JE (1985) Fertilizantes orgânicos. Agronômica Ceres, Piracicaba

24. Xu H, Yang X, Xie L, Hakkarainen M (2016) Biomacromolecules 17:985

25. ABNT-Associação Brasileira de Normas Técnicas (2004) NBR 10.006: procedimento para obtenção de extrato solubilizado de resíduos sólidos. ABNT, Rio de Janeiro

26. Rank J, Nielsen MH (1997) Mutat Res 390:121

27. Grant WF (1982) Mutat Res 99:273

28. OECD 208 (2006) Terrestrial plant test: seedling emergence and seedling growth test

29. Gariglio NF, Buyati MA, Pillati RA, Russia DEG, Acosta MR (2002) NZJ Crop Hortic Sci 30:135

30. Fernandes TCC, Mazzeo DEC, Marin-Morales MA (2009) Ecotoxicol Environ Saf 72:1680

31. Odeigah PGC, Nurudeen O, Amund OO (1997) Heredita 126:161

32. Serrano-Garcia L, Monteiro-Montoya R (2001) Environ Mol Mutagen 38:38

33. Fernandes TCC (2005) Investigação dos efeitos tóxicos, mutagênicos e genotóxicos do herbicida trifluralina, utilizando Allium cepa e Oreochromis niloticus como sistemas-teste. Dissertação de Mestrado em Biologia Celular e Molecular-Instituto de Biociências-UNESP, Rio Claro, SP

34. Leme DM, Agnelis DF, Marin-Morales MA (2008) Aquat Toxicol 88:214

35. Mazzeo DEC, Fernandes TCC, Marin-Morales MA (2011) Chemosphere 85:13

36. Rank J, Nielsen MH (1998) Mutat Res 418:113 